\title{
Languange Shift and Language Maintenance of Local Languages toward Indonesian
}

\author{
Umi Farisiyah \\ Applied Linguistics Department \\ Yogyakarta State University \\ Yogyakarta, Indonesia \\ farisiyahumi@yahoo.com
}

\author{
Zamzani \\ Applied Linguistics Department \\ Yogyakarta State University \\ Yogyakarta, Indonesia \\ zamzani@uny.ac.id
}

\begin{abstract}
This study was aimed to investigate the tendency of daily language use by Indonesians and the preference of the use of local languages or Indonesian in everyday life. This is to know whether there is language shift and maintenance of local languages toward Indonesian. The participants were 201 respondents from several provinces in Indonesia (almost every province in Indonesia was represented). The method used in this study was descriptive quantitative. Data collection technique was the survey questionnaire. The result from this study revealed that Indonesians have positive attitude toward the use of local languages they have. The data gained showed that the majority of respondents prefer using local language to Indonesian in the family and neighborhood domains, the places where they spend almost all their time in. Yet, Indonesian is often used in the educational and general places due to the demand and the effectiveness of communication. Importantly, the finding from this study demonstrates that Local languages have not been shifted yet because they are still frequently used in the family and neighborhood area. In other words, local languages are not shifted, yet maintained though in educational and general places are in the contrary. This phenomenon includes in one effort to preserve the local languages that Indonesia has to the next generation.
\end{abstract}

Keywords- local language; language shift; language maintenance.

\section{INTRODUCTION}

The Republic of Indonesia is a very large nation with a correspondingly large population and great linguistic diversity. The nation extends over almost 3,000 kilometers: from Banda Aceh at the western tip of Sumatera to Kupang in West Papua is approximately 2,830 kilometers. Estimates vary, but the nation includes somewhere in the region of 17,000 islands of which 6,000 are inhabited. This makes Indonesia be the 14th largest nation on earth by land area. According to the national census of 2000, the population then was 206,264,595 (Statistics Indonesia, accessed Aug. 24, 2017), making Indonesia the fourth largest nation on earth by population. Ethnologue 15 [1] lists Indonesia as having 742 languages spoken within its borders. Based on the data, it is obvious that Indonesia includes a country with multiethnic, Multilanguage and multicultural society.

In the context of multilingual, multiethnic, and multicultural language in Indonesia with the high intensity of contact between one ethnic group and the other groups, linguistic competition is inevitable. Moreover, if the competition is linked to the rapid and comprehensive development of Indonesian in almost every group of people, the phenomenon of local language shift is also manifested not only by the decreasing interest of young people to learn local languages as their local identity but also the increasing tendency of parents who come from one tribal family to choose to use Indonesian (I) as their main communication tool at home than their local languages (LL). This indicates that the domain of LL use in the household is gradually getting shifted by I, which also has triggered the so-called "language shift".

The phenomena of defense and shifting of these LL have been widely studied by researchers. Various research results in many languages, especially in Papua and Maluku, are reported to be extinct or endangered, some even extinct, as reported by International SIL. Similarly in Sulawesi, there are several languages whose speakers are several thousand or even hundreds are in critical condition, waiting to be abandoned by speakers, such as Panasuan, Talondo, Napu [2]. Not to mention in Palu, the capital of Central Sulawesi Province, as reported by Basri [3], Kaili language which is the original LL of the largest ethnic group, the Kaili tribe in Palu including in the process of shifted as most families no longer use it with their children and grandchildren. As a result, within a few generations will leave the earth itself if not immediately taken constructive steps to enable the use (revitalization) among members of the Kaili tribe family.

Some of LL in Indonesia began to be feared by many people, especially the older generation, threatened being shifted by the use of I among the younger generation. This research is intended to address these concerns and seeks answers to the question: "Is it true that the younger generation has switched to Indonesian (I) as their home language substitute for local language (LL)?"

\section{REVIEW OF LITERATURE}

\section{A. Local Languages in Indonesia}

In Ethnologue: Language of The World [1] argued that in Indonesia there are 742 languages, and 737 languages are still alive or still used by their speakers. In the meantime, there are two languages that play a role as a second language with no mother tongue, while the other three languages have become extinct. Those languages so far are called as local languages. Some languages are still existed but they are on the verge of extinction. They are caused by the decrease in the number of speakers because the native speakers who are still alive are only 
a few people. On the other hand, there are also local languages urged by the influence of other local languages which is more dominant. Not to mention, the influence of the use of Indonesian as a national language, especially in various formal spheres, also take part. In addition, the condition of Indonesian society that is multiethnic absolutely opens up opportunities to support language contact through communication and interaction between different languages and cultures.

Multiethnic community conditions and followed by contacts intercultural including language contact may result various linguistic phenomena such as bilingualism (or even multilingualism) that often occurs in language groups minority. The language contact may also result language shift. Furthermore, the flow of information and communication along with various other symptoms arising from the spectrum of activity and the increasingly oriented use of the language of today's global society also helped trigger the emergence of various problems of language, including the issue of local language extinction.

The phenomena mentioned above interesting to investigate because these phenomena can be a condition that leads to the extinction of a language. This is what has been the concern of various circles, especially the linguists who are very interested in this field. That matter is certainly very reasonable because the impact of language extinction phenomenon is not for the linguistic dimension itself, but can also have implications for the cultural dimensions of society inherently attached to the language.

\section{B. Language Shift and Language Maintenance}

According to Longman Dictionary of Language Teaching and Applied Linguistics, language maintenance is the degree to which an individual or group continues to use their language, particularly in a bilingual or multilingual area or among immigrant groups; whereas language shift is the process by which a new language is acquired by a community usually resulting with the loss of the community's first language. Both language maintenance and language shift are the results of language contact situations. Since the publication of Fishman's [4] Language Loyalty in the United States, there has been significantly a great amount of research on language maintenance and language shift (LMLS) as a linguistic contact phenomenon. Language maintenance refers to the situation where speech community continues to use its traditional language in the face of a host of conditions that might foster a shift to another language [5]. It is the product of language contact where a linguistic minority or a dominated ethno linguistic group is successful in keeping its original language in spite of the pressure exhorted on it by a dominant linguistic group. Language shift, on the other hand, means that a community gives up entirely its language in favour of another one [4].

More research on LMLS has been conducted in different contexts (see [6]-[13]). Recently, Sun [14] found that the importance of parental roles in Chinese language maintenance. In another study, Cashman [15] examined the individual variables such as age at time of arrival and social network had the most significant impact on the Spanish language.
Park [16] in his research, maintaining Korean as a heritage language, found that Korean is used more with the parents' generation and English is predominantly used among peers in the younger generations. Van Aswegen [17] studied language maintenance and shift of Maale, and the findings indicated that the mother tongue literacy programme contributed to language maintenance. Martin [18] carried out a research on Arab American parents' attitudes toward their children's heritage language maintenance and language practices. Results indicated that parents hold positive attitudes towards Arabic and engage in various language practices that promote the maintenance of Arabic in their families, and racism is not significantly associated with language attitudes or language encouragement.

\section{METHODOLOGY}

The aim of this study is to examine language maintenance and language shift of local languages toward Indonesian. This study was conducted using descriptive statistics. For the purpose of the current research, the survey questionnaire was conducted. The survey questionnaire through Google Form contains a list of 15 questions about language usage and choice of respondents as used by Gal [19] against Hungarian, Fasold [20] for Tiwa Indian, and Gunarwan [21] for Lampung. In the questionnaire was asked what language is used at home in everyday conversations with family members or in family gatherings (family area with parents, grandparents, brothers/sisters, wife/husband, and housework assistant), neighbors (neighboring sphere with neighbors, relatives, guests), at school (education sphere with teachers, lecturers, students/friends), in the office (sphere of government), on the streets, in markets or in public places (public sphere), and in religious studies. The language options used are assigned using scale as follows: Always (almost always) LL, More frequent LL than I, Equal frequent I and LL, I more frequent than LL, and Always (almost always) I.

In this study, data were analyzed interpretively and thematically based on a number of categorization areas: language shift, language maintenance, local language, family, neighborhood, educational and public domains. Coding was also used to label those categorization areas: LL (Local Language), and I (Indonesian).

Questionnaire questions in Google form were adapted from questionnaire form from collaborative research conducted by researchers at the Center for Language and Culture Studies (PKBB), Atma Jaya Unika and Jakarta Field Station, Max Planck Institute for Evolutionary Anthropology. There were 15 questions proposed according to some domains of communication. The domains were represented from the family domain, the neighboring domain, the educational and the general/ public domain. Questionnaires were randomly divided via whats app in order to capture as many local languages as possible. Therefore, the result can draw the phenomena of language shift and maintenance of LL toward $I$. the questionnaire was spread for 5 days.

\section{FINDINGS AND DISCUSSIONS}

\section{A. Findings}

From a week spreading the questionnaire, the respondents obtained filling out the questionnaire was 201 respondents consisting of 115 female and 86 male respondents. The 
respondents come from many provinces in Indonesia covering almost all big islands in Indonesia (Sumatra, Java, Kalimantan, Sulawesi, and Nusa Tenggara). The ages and occupations of the respondents are also various with the youngest respondent is 18 years old and the oldest is 54 years old as well as the lowest and the highest educational background is senior high school and postgraduate.

The vast majority of the respondents are from Java with the range of age between 21-26 and university students as the occupation. For the clearer description of the respondents, the table 1 illustrates clearer about it.

TABLE I. PARTICIPANTS’ DESCRIPTION

\begin{tabular}{|c|c|c|c|c|c|}
\hline \multicolumn{6}{|c|}{ Respondents' Description } \\
\hline Provinces & $N$ & Age & $N$ & Occupation & $N$ \\
\hline Aceh & 1 & $15-20$ & 30 & Doctor & 1 \\
\hline Banten & 4 & $21-26$ & 112 & Employees & 30 \\
\hline Jakarta & 6 & $27-32$ & 40 & Entrepreneurs & 8 \\
\hline Java & 127 & & & Housewives & 11 \\
\hline Kalimantan & 11 & $33-38$ & 10 & Lecturers & 30 \\
\hline Maluku & 2 & & & Midwife & 1 \\
\hline $\begin{array}{l}\text { West/East } \\
\text { Nusa } \\
\text { Tenggara }\end{array}$ & 9 & $39-44$ & 4 & $\begin{array}{l}\begin{array}{l}\text { University } \\
\text { (mostly }\end{array} \text { Students } \\
\text { program) }\end{array}$ & 85 \\
\hline Sumatra & 21 & $45-50$ & 4 & Civil servant & 3 \\
\hline Sulawesi & 10 & \multirow{2}{*}{$\begin{array}{l}\text { Over } \\
50\end{array}$} & \multirow[t]{2}{*}{1} & Teachers & 28 \\
\hline Yogyakarta & 10 & & & Unemployed & 4 \\
\hline & 201 & & 201 & & 201 \\
\hline
\end{tabular}

TABLE II. THE PERCENTAGE OF QUESTIONNAIRE RESULT

\begin{tabular}{|l|l|c|c|c|c|}
\hline \multirow{2}{*}{ Domain } & \multicolumn{5}{|c|}{ Scale } \\
\cline { 2 - 6 } & Always LL & $\begin{array}{c}\text { More } \\
\text { frequent LL }\end{array}$ & $\begin{array}{c}\text { Equal LL } \\
\text { and I }\end{array}$ & $\begin{array}{c}\text { More } \\
\text { frequent } \\
\text { I }\end{array}$ & Always I \\
\hline Family & $44.18 \%$ & $21.07 \%$ & $10.17 \%$ & $14.20 \%$ & $10.38 \%$ \\
\hline Neighborhood & $26.85 \%$ & $21.55 \%$ & $16.95 \%$ & $19 \%$ & $14.65 \%$ \\
\hline Educational & $3 \%$ & $6.95 \%$ & $17.45 \%$ & $37.05 \%$ & $35.55 \%$ \\
\hline Public & $9.67 \%$ & $17.67 \%$ & $21.90 \%$ & $29.85 \%$ & $20.90 \%$ \\
\hline
\end{tabular}

\section{B. Discussion}

The following will be discussed the results of survey questionnaires about the use of local language and Indonesian language daily in various domains.

\section{1) Family domain}

In the context of this study, what is to be seen is whether the dominance of I of LL on Indonesian society from various provinces has caused local language shift or maintenance. According to the choices of answers provided in the questionnaire, it was found that the overall percentage of the respondent's choice of language of all age groups $(\mathrm{N}=201)$ was that the respondents are always (almost always) using LL than I in their family environment; communication with parents, brothers/sisters, grandparents, and relatives.
This suggests that in intra-family communication at home, $\mathrm{LL}$ is always or almost always used. According to the comparison of percentage of answers using LL and I, the use of LL is considered high. 44.18\% from 201 respondents (93 respondents) states that they always use LL in their family domain and $21.07 \%$ or 42 respondents claim that they are more frequent using LL than $\mathrm{I}$. The data gained indicates that respondents from various provinces in Indonesia tend to use their local language in their daily life to communicate with their family. This is in accordance with the opinion of the Community stating that the use of local language plays an important role in terms of culture. By using the local language, we have unconsciously used the Culture of the Region itself, and by using the local language people know we are people who come from the area. So that local language has an important role in preserving the culture of the region".

The family is the place where mothers (parents) continue their inheritance to their children from one generation to the next. In other words, family is a place of preserving cultural inheritance. According to Fishman [22], in the family domain, there is intense communication between the mother-father, the siblings, the parents-children, grandparents, and other family members so that the process of transferring the language from the older generation to the younger generation can run. Usually communication within the household is concerned with various things and various other life issues. Here also can be seen patterns of language usage of all members of the family when they communicate in the house. So, as long as the families are still willing to use their mother-tongue (LL) at home as the primary means of communication, LL will still be able to survive.

\section{2) Neighborhood Domain}

In the neighborhood domain, it shows that in the neighbors' living environment LL speakers are still more frequently used than I, except for communication to guests and to the village boards. This is because the usual topic in this context is not the topic of everyday life. While with the guests, the percentage between using LL and I is almost balanced. This is because the background of the guest who is not always a local area with the respondent. Based on the result percentage of $\mathrm{LL}$ in neighborhood area, 26.85\%, according to sociolinguistic experts, may imply two things. First, there is the possibility of the emergence of symptoms of so-called infiltration or diglosia leakage. Second, such linguistic situations are commonplace in a bilingual society. For the first group, if there is a symptom of pervasive use of the second language in the family and neighborhood, then it indicates the beginning of the shift of language.

However, for a second group, such a thing should not be concerned because it is a common phenomenon that can be found in bilingual communities everywhere. A common reason is that certain topics of conversation may be discussed in a particular language regardless of the location of the conversation or the speaker [23]. From the explanation above, it is obvious that LL still defends in neighborhood area. Though I is sometimes used, but it does not replace the frequency of using LL in doing communication. 


\section{3) Educational Domain}

The educational domain revolves around the communication situation around the school, not only in the classroom, when the activities of teaching and learning are in progress, but also situations when playing with friends outside the classroom or school-side, in the school cafeteria, or in the classroom during breaks. There are two situations that are posed to the respondent to be answered in the questionnaire, which is related to the language used when speaking to teachers/ lecturers inside and outside of the classroom, and to friends.

The result of data processing of percentage of choice of language in educational domain based on education level of respondent shows that the use of I is bigger than LL. From the table 2, 37.05\% more frequent I than LL and 35.55\% always use I indicates that I is dominantly used in educational domain. This is because of the demand of education itself. In educational field, the topics or the issues discussed are about scientific things. Regard to this, the use of I is more appropriate. Based on the group of data descriptions, the vast majority of the respondents are those who are well-educated (it can be seen from the amount of respondents who are still study and their occupation in table 1), this can be compiled that the higher the education level of respondents the higher the tendency to use I.

\section{4) Public Domain}

The pattern of language usage in certain situations; in a public place, in public transportation, meeting their fellow outside the village, meeting unknown merchants in the village, and in a forum or seminar or symposium is different from language usage in family domain.

The results showed that in situations such as riding public transportation, assembling with fellow citizens outside the village, generally the language used is almost always I. Based on the percentage of community language choices in the abovementioned situations, all of which are more general in nature, it can be understood that the rate of using I is greater than that of LL. This can be due to anticipating of misunderstanding. Usually, in a public place, people come from various places with different LL. It is the same as language use when communicating with guests. At home, LL is the main choice or a major communication tool among all family members. However, when being outdoors, as they may meet different backgrounds, interests, settings and communication objectives, it is possible to move to a language used for a broader purpose (language for wider communication) becomes larger and becomes first choice. This is also in line with the data questionnaire gained for the public domain, 29.85\% more frequent I than LL and $20.90 \%$ always use I.

Then, when seen from the differences in age groups it appears that there is little difference and shift between the young age group, adult age, and old age. The younger age group appears to be more likely to switch to I than LL. This result is the same as Letsolo [24] carried out a research on language maintenance or shift through investigating the attitudes of Bakalanga youth towards their mother tongue. The results showed that informants used Setswana frequently, even in domains where they could use their mother tongue, e.g. when speaking to peers from the same mother tongue. Some of the subjects also expressed negative feelings towards using their mother tongue around non-native speakers of the language.

The question is whether the linguistic phenomenon and the stable bilingualism is only a temporal phenomenon or will it last forever?. The answer is certainly on the speakers and supporters of the language itself as well as other external and internal factors that support the preservation of the language.

\section{CONCLUSION}

The highlight of this study is to know the language preference of Indonesians in their daily life. They prefer using LL or I to communicate with their family, neighbors and in general places. The result of the study is able to draw language shift and language maintenance of LL toward I. Empirically, based on the percentage of choice of language in the family, neighborhood, and general domains in using LL as their communication tool can be concluded that LL will still survive. Yet, there is a tendency that the younger age group of respondents appear to be the greater percentage of their language choices. However, it only shows the frequency of interaction in various interaction situations, which is a common and natural phenomenon in the diglossic society caused by socialpsychological factors that occur among speakers. It is still far from the tendency of a shift towards a monolingual society of BI, as it affects the Kaili language in Palu city, as Basri [3] reported.

Theoretically, based on the experiences of other languages in the world experiencing threats as well as Lampung in Indonesia [21], Arvanitic, Albanian-speaking in Greek [25] or Hungarian in the Oberwart village of the Austrian-German border [19], the languidly threatened language is a language no longer used by the younger generation at home with his family, living only by the older generations. Typologically, Krauss [26], which classifies the languages of the world into three types (extinct, endangered, and still safe), LL is still relatively safe, perhaps even very safe, since LL demographics still have considerable speakers and is supported by patterns of home language usage that can ensure intergenerational mother tongue continuity. In addition, the use of LL in education received support from the government, as evidenced by the teaching of local languages as a local content in schools, and protected also by the law as a cultural heritage of the nation.

The tendency to use I as a mother tongue to replace LL at home is still limited to be tolerated. The concern of the older generation that the younger generation tends to use I if it is spoken is only a psychological phenomenon of language that also occurs in other speakers of other languages who know the level of language such as Javanese. Based on the survey only a small percentage of respondents $(\mathrm{N}=201)$ who actually use I as their mother tongue since childhood and in their everyday life. Although overall the average younger generation uses I as often as LL outside the home, it is just a common symptom of bilingual society.

\section{ACKNOWLEDGMENT}

The researcher thanks to all respondents being so kind and cooperative to fill out the questionnaire during the data collection process of this study. Furthermore, Umi Farisiyah expresses grateful feeling to Indonesian Endowment Fund for 
Education/ Lembaga Pengelola Dana Pendidikan for funding her fully in pursuing Master degree in Applied Linguistics Department of Yogyakarta State University, Indonesia.

\section{REFERENCES}

[1] R. G. Gordon Jr., Ethnologue: Languages of the World, 15th ed., Ed. Dallas, TX: SIL International, $2005 . \quad$ [Online]. Available: http://www.ethnologue.com/.

[2] B. F. Grimes, "Kecenderungan Bahasa untuk Hidup atau Mati secara Global (Global Language Viability): Sebab, Gejala, dan Pemulihan untuk Bahasa-Bahasa yang Terancam Punah [Language Tendency to Live or Die Globally (Global Language Viability): Cause, Symptoms, and Recovery for Endangered Language]," in PELBBA 15, B. K. Purwo, ed.. Jakarta: Lembaga Bahasa Atma Jaya, 2002.

[3] H. Basri, "Menuju Generasi Monolingual di Kota Palu [Towards Monolingual Generation in Palu City]," Ling. Indo., vol. 26, no. 2, pp. $169-183,2008$.

[4] J. A. Fishman, Language Loyalty in the United States. The Hague: Mouton, 1966.

[5] H. A. Habtoor, "Language Maintenance and Language Shift among Second Generation Tigrinya-speaking Eritrean Immigrants in Saudi Arabia,” Theory and Practice in Lang. Stud., vol. 2, no. 5, pp. 945-955, 2012.

[6] F. Okamura, "Mother tongue maintenance and development among the Japanese children living in the united states," Unpublished Ph.D. Thesis, University of California, Los Angeles, 1981. AAT 8206061. [Online]. Available: http://proquest.umi.com. [Accessed Apr. 15, 2017].

[7] N. T. Morgan, "Language maintenance and shift amon Haitians in the Dominican Republic,” Ph.D. dissertation, The University of New Mexico, 1987. AAT 8808137. [Online]. Available: http://proquest.umi.com. [Accessed Jun. 17, 2017].

[8] K. L. Brook, "Language maintenance in the Japanese American community in the Los Angeles area," Unpublished M.A thesis, California State Univ., Long Beach, 1988. AAT 1335085. [Online]. Available: http://proquest.umi.com. [Accessed Mar. 7, 2017].

[9] N. M. Yakoubu, "Sociolinguistic inquiry into language maintenance and language shift among sub-Saharan Africans in the United States of America: An example in western Pennsylvania," Ph.D. dissertation, Indiana University of Pennsylvania, 1994. AAT 9412974. [Online]. Available: http://proquest.umi.com. [Accessed Apr. 16, 2017].

[10] N. Kostoulas-Makrakis, "Language maintenance or shift? A study of Greek background students in Sweden,” Ph.D. dissertation, Stockholm Universitet, Sweden, 1995. AAT C435258. [Online].
[ Available: http://proquest.umi.com. [Accessed Apr. 12, 2017].

[11] M. Saxena, "A sociolinguistic study of Panjabi Hindus in Southall: Language maintenance and shift,” D.Phil. dissertation. The University of York (United Kingdom), 1995. AAT C505148. [Online]. Available: http://proquest.umi.com. [Accessed Apr. 9, 2017].
[12] S. Stoessel, "The investigation of social networks as a factor in language maintenance and shift,” Ph.D. dissertation, Boston University, 1998. AAT 9825415. [Online]. Available: http://proquest.umi.com. [Accessed Jan. 23, 2017]

[13] K. E. Somerholter, "Language contact and shift in the Soviet German speech community," Ph.D. dissertation, The University of Texas at Austin, 1999. AAT 9947394. [Online]. Available: http://proquest.umi.com. [Accessed Mar. 1, 2017].

[14] L. Sun, "First language maintenance in recent Chinese immigran families," Ed. D. dissertation, Texas Tech University, 2000. AAT 9963539. [Online]. Available: http://proquest.umi.com. [Accessed Dec. 23, 2017].

[15] H. R. Cashman, "Doing being bilingual: Language maintenance, language shift, and conversational code-switching in southwest Detroit," Ph.D. dissertation, University of Michigan, 2001. AAT 3016817. [Online]. Available: http://proquest.umi.com. [Accessed on May 16, 2017].

[16] C. Y. Park, “Maintaining Korean as a heritage language,” Ph.D. dissertation, Arizona State University. AAT 3287994. [Online]. Available: http://proquest.umi.com. [Accessed Apr. 12, 2017].

[17] J. G. van Aswegen, "Language maintenance and shift in Ethiopia: The case of Maale,” M. A. Thesis, University of South Africa (South Africa) 2008. AAT 0669289. [Online]. Available: http://proquest.umi.com, [Accessed Mar. 22, 2017]

[18] N. Martin, "Arab American parents' attitudes toward their children's heritage language maintenance and language practices," unpublished M.A. thesis, The University of North Carolina at Chapel Hill, 2009. AAT 1472860. [Online]. Available: http://proquest.umi.com. [Accessed on May 20, 2017].

[19] S. Gal, Language Shift: Social Determinants of Linguistic Change in Bilingual Austria. New York: Academic Press, 1979.

[20] R. Fasold, The Sociolinguistics of Society. Oxford: Basil Blackwell Ferguson, 1984

[21] A. Gunarwan, "Indonesian and Balinese among Native Speakers of Balinese: A Case of Stable Bilingualism?” Paper presented at the Third International Symposium on Bilingualism, Bristol, UK, Apr. 17 - 20 April 2001.

[22] J. A. Fishman, "The Sociology of Language: Yesterday, Today, and Tomorrow,” in Current Issues in Linguistic Theory, R. Cole, ed. Bloomington: Indiana University Press, 1977.

[23] J. J. Holmes, An Introduction to Sociolinguistics. New York: Longman Publishing, 1992.

[24] R. Letsholo, "Language maintenance or shift? Attitudes of Bakalang youth towards their mother tongue," International Journal of Bilingual Education and Bilingualism, vol. 12, no. 5, pp. 581-595, 2009.

[25] H. Giles, "Sociolinguistics and Social Psychology: An Introductory Essay," in Language and Social Psychology, H. Giles \& R. St. Calair (Eds.). Oxford: Basil Blackwell, 1979.

[26] M. Krauss, “The World's Languages in Crisis,”Language, vol. 68, pp 4 10, 1992. 